\title{
ANTIQUITY
}

Acknowledgements : I must place on record my indebtness to the many friends and colleagues who have assisted me in preparing this note: in particular, Dr R. Wyss has generously allowed me access to his unpublished material relating to the sword, its chronology and associations; my friend and former teacher, Professor L. J. D. Richardson, has been more than generous with advice on philological matters. I have also benefited from discussion with Mr T. G. E. Powell, Professor Stuart Piggott, Professor J. M. C. Toynbee and Professor R. Geraint Gruffydd. None of these people is responsible for any misuse I have made of their information. COGHLAN, H. H. 1956. Notes on prehistoric and early iron in the Old World (Oxford).

CONWAY, R. S. 1897 . The Italic dialects (Cambridge). EVANs, E. E. 1967. Gaulish personal names (Oxford).
FulIP, J. 1960. Celtic civilisation and its heritage (Prague).

HOLDER, A. 1913. Altkeltische Sprachschatz (Teubner, 1896-1913).

JOACHIM, H.-E. I 969 . Unbekannte Wagengräber der Mittel- bis Spätlatenezeit aus dem Rheinland, in (ed.), O.-H. Frey, Marburger Beiträge zur Archäologie der Kelten, Festschrift Dehn, Fundberichte aus Hessen, I, 84-1 I1.

IIEB, H. r955. See under Wyss.

PIGgotT, S. 1965. Ancient Europe (Edinburgh). 1968. The Druids (London).

POWELL, T. G. E. 1958. The Celts (London).

ventris, M. and J. CHADWICK. 1956. Documents in Mycenaean Greek (Cambridge).

wyss, R. 1955. Das Schwert des Korisios, Arch. Helvetica, v, 201-22.

\section{Witchcraft at barrows and other prehistoric sites}

This note is published in the hope that it may attract more information on this subject. The belief in witchcraft assumed alarming proportions in England from the mid-16th to the $x 8$ th century, largely as the result of influence from the continent where it was rife, particularly in Italy and the Iberian peninsula.

One of the earliest recorded instances is the Examination of John Walsh before Maister T. Williams in 1566 (see Murray, I92 I, 240; Grinsell, 1953, 76-7). John Walsh was of Netherbury, Dorset:

He being demaunded how he knoweth when anye man is bewytched: he sayth that he knew it partlye by the Feries, and sayth that ther be iii kindes of Feries, white, greene, and black. Which when he is disposed to vse, hee speaketh with them upon hyls, where as there is great heapes of earth, as namely in Dorsetshire. And betwene the houres of xii and one at noone, or at midnight he vseth them. Whereof (he sayth) the black Feries be the woorst.

There is a barrow in Netherbury parish which was omitted from Dorset Barrows (Grinsell, 1959) but has since been tracked down by N. H. Field (pers. comm., the site is north of Emmanuel Cross at SY $45899 \mathrm{r}$ ).

In medieval times there seems to have been a close connexion between witches and fairies; and any barrow with a fairy tradition dating back to this period might have been associated with witchcraft.

The writer is grateful to $\mathrm{Mr}$ James Dyer for the following reference from the trial of Elizabeth Pratt of Dunstable, Bedfordshire, from the Bedfordshire Assize Roll for ${ }_{1} 667$ (Curtis, 1957):

Elizabeth Pratt, when asked about two children of Thomas Heyward who were said to have been bewitched to death, accused instead three other Dunstable women. She said that 'the devill appeared to her about a fortnight since in the form of a catt, and Commanded (her) to goe to those three persons aforesaid to seeke the destroying of the two Children...' She said she was with them when they mett to bewitch the eldest childe of the said Heyward, and that they had two meetings about it whereof one was at the Three Knolls upon the Dunstable Downes, and the other a little lower upon the said Downes.

The 'Three Knolls' are of course the wellknown group of barrows now known as the Five Knolls on Dunstable Downs. Elizabeth Pratt was committed to Bedford Gaol where her name occurs next to that of John Bunyan in the prison register.

A suggestion that Nan Tow's Tump (Glos.) is named from a witch remains unproved (O'Neil and Grinsell, I961, 52).

The remaining references are concerned with what appears to be the association of witch cult specimens with barrows and other prehistoric sites. Somewhat vague references 


\section{NOTES AND NEWS}

to the mid-xgth century finding of human hair in a stone cist on Whiten Tor (Dartmoor) and in another stone cist on Dartmoor, the location of which was not clearly stated (Bray, 1879, 99; cf. Burnard, I890, 201) are strengthened by the finding of two large coils of human hair in a stone cist on Soussons Common, Postbridge, Dartmoor, abour 1902. They were submitted to F. T. Elworthy, author of The evil eye, who pronounced them to be relics of witcheraft comprising the casting of a spell on the former possessor of the hair (Elworthy, I895, 71, 416; Grinsell, 1953, 132; Worth, 1903, I42; 1904, I01; 1953, 191). In 1939 the late G. B. Gardner, author of a work on witchcraft and sometime owner of the Museum of Witchcraft at Castletown in the Isle of Man, exhibited before the Folk-lore Society, and subsequently published in Folklore, an object described by him as a Witch's Moon-dial, used by witches at midnight. It is of human bone with seven sections corresponding to the Seven Hours of Dread. It is said to have been found near Wayland's Smithy in Berkshire (Gardner, 1939, 190 and pl. VII). Mention might also be made of the human skull (analysed through the Birmingham City Museum \& Art Gallery and found to be modern) found at Wayland's Smithy, reputed to have been previously owned by 'Mary Chalmers, a woman of skill in the curing of cows and sheep', who died on $4^{\text {th }}$ June 1810 and lived at Little Moreton near Didcot (Grinsell, 1939, 135-9).

In August 196I, James Dyer excavated a kidney-shaped barrow on Galley Hill, Streatley, north of Luton (Bedfordshire). In addition to neolithic and later burials, it contained a pit $1.3 \mathrm{~m}$. deep, in which were traces of a wooden post (of a gallows?), a piece of Cistercian ware (I 4 th- or 15 th-century?), a horse's skull, and a chalk dice (no. 6 uppermost). The horse's skull and dice were thought by Dr Margaret Murray to be witchcraft relics (pers. comm. to James Dyer).

Finally, in the museum of Witchcraft at Boscastle, Cornwall, is a witch's split-ended hazel wand, used at the Rollright Stones at dawn on I May 1955. This illustrates the latter-day revival of Witch Covens, etc., and the occasional choice of prehistoric sites for their meetings.

L. V. GRINSELL

BRAY, E. A. 1879. Borders of the Tamar and the Tavy. BURNarD, R. 1890 . Notes on Dartmoor kistvaens, Trans. Devon. Assoc., xxII, 200-207.

CURTIS, E. 1957. Crime in Bedfordshire $1660-1688$, 9-10. (Published by Bedfordshire County Record Office).

ELWORTHY, F. T. 1895. The evil eye.

GARDNER, G. B. I939. Witchcraft, Folk-lore, L, I8890.

GRINSELL, L. V. I939. Notes on the White Horse Hill region, Berkshire Archaeol. F., XLIIr, I 35-9.

1953. The ancient burial-mounds of England.

1959. Dorset barrows.

MURRAY, M. A. I92. The witch cult in western Europe. o'NEIL, H. and L. V. GRINSELL, I 96r. Gloucestershire Barrows, Trans. Bristol \& Glos. Archaeol. Soc., LXXIX, I-I 49 .

WORTH, R, H. 1953. Dartmoor.

WORTH, R. H. (ed.). I 903 . Twenty-second report of the Barrow Committee, Trans. Devon Assoc., XXXV, I 40-2.

I 904. Twenty-third report of the Barrow Committee, Trans. Devon Assoc, XXxvI, IOI-2.

\section{RCHM (England): NMR: The Air Photographs Unit}

The current pressures on land, such as new town development, motorways, new agricultural methods, mineral extraction, and a host of other activities, all combine to place much archaeological evidence at risk; and the corollary to this is the rapid identification and assessment of sites so that suitable action may be determined. The importance of air photography as a reconnaissance medium can hardly be exaggerated. Dr J. K. S. St Joseph's pre-eminent work in this field will be well known to readers of ANTrQUITY, but there are also many tens of thousands of air photographs taken every year for a variety of purposes, including some for archaeology, and it is against this background that the activities of the Air Photographs Unit of the National Monuments Record must be seen.

The Unit was formed late in 1965 to provide a record of those features which could be 